Article

\title{
Adsorption and Desorption Performance and Mechanism of Tetracycline Hydrochloride by Activated Carbon-Based Adsorbents Derived from Sugar Cane Bagasse Activated with $\mathrm{ZnCl}_{2}$
}

\author{
Yixin Cai ${ }^{1,2}$, Liming Liu ${ }^{1,2}$, Huafeng Tian ${ }^{1, *}$, Zhennai Yang ${ }^{1, *}$ and Xiaogang Luo ${ }^{1,2,3, *}$ \\ 1 Beijing Advanced Innovation Center for Food Nutrition and Human Health, Beijing Technology \& Business \\ University (BTBU), Beijing 100048, China; yxcai0507@outlook.com (Y.C.); 15172490904@163.com (L.L.) \\ 2 School of Chemical Engineering and Pharmacy, Wuhan Institute of Technology, LiuFang Campus, \\ No.206, Guanggu 1st road, Donghu New \& High Technology Development Zone, \\ Wuhan 430205, Hubei Province, China \\ 3 School of Materials Science and Engineering, Zhengzhou University, No.100 Science Avenue, \\ Zhengzhou 450001, Henan Province, China \\ * Correspondence: tianhuafeng@th.btbu.edu.cn (H.T.); yangzhennai@th.btbu.edu.cn (Z.Y.); \\ xgluo0310@hotmail.com or xgluo@wit.edu.cn (X.L.); Tel.: +86-139-8627-0668 (X.L.)
}

Received: 4 November 2019; Accepted: 9 December 2019; Published: 11 December 2019

\begin{abstract}
Adsorption and desorption behaviors of tetracycline hydrochloride by activated carbon-based adsorbents derived from sugar cane bagasse modified with $\mathrm{ZnCl}_{2}$ were investigated. The activated carbon was tested by SEM, EDX, BET, XRD, FTIR, and XPS. This activated carbon exhibited a high BET surface area of $831 \mathrm{~m}^{2} \mathrm{~g}^{-1}$ with the average pore diameter and pore volume reaching $2.52 \mathrm{~nm}$ and $0.45 \mathrm{~m}^{3} \mathrm{~g}^{-1}$, respectively. The batch experimental results can be described by Freundlich equation, pseudo-second-order kinetics, and the intraparticle diffusion model, while the maximum adsorption capacity reached $239.6 \mathrm{mg} \mathrm{g}^{-1}$ under $318 \mathrm{~K}$. The effects of flow rate, bed height, initial concentration, and temperature were studied in fixed bed adsorption experiments, and adsorption data were fitted with six dynamic adsorption models. The results of characterizations and the batch experiments were analyzed to study the adsorption and desorption mechanisms. Tetracycline hydrochloride and activated carbon were bonded together by $\pi-\pi$ interactions and cation $-\pi$ bonds. Ethanol was used as an eluent which bonded with 10 hydrogen bond acceptors on tetracycline hydrochloride to form a complex by hydrogen bonding to achieve recycling.
\end{abstract}

Keywords: adsorption; desorption; mechanism; sugar cane bagasse; activated carbons; tetracycline

\section{Introduction}

Tetracycline $(\mathrm{TCH})$ is the most widely used veterinary and human antibiotics type [1,2], however, approximately $50 \%-80 \%$ of the ingested $\mathrm{TCH}$ is excreted from the body through the urinary system [3]. $\mathrm{TCH}$ is a harmful residue if it is not been adequately pre-treated and is released into the soil or aquatic environment [4]. Generally, TCH with a low concentration $\left(<1 \mathrm{mg} \mathrm{L}^{-1}\right)$ in natural waters arouses great concerns of toxic effects and may have the potential to spread antibiotic resistant genes. It is an urgent task for us to remove the low concentrations of TCH for safe water supplies. The adsorptive method is a good solution, but it requires adsorbents with high adsorption capacity.

Activated carbon (AC) provides a stronger adsorption affinity to adsorbate among other adsorbents [5]. It is a low-cost and environmentally friendly choice, as a large number of abandoned bagasse resources are used to prepare activated carbon. Bagasse is not only rich in $C$ atoms but also 
has numerous -OH groups, some of which remain in the pyrolysis, while other parts forms new chemically-reactive oxygen functional groups [6]. AC contains not only a benzene ring but also many chemically reactive oxygen functional groups $(-\mathrm{OH},-\mathrm{COOH}$, etc.), which can be used for chemical modification [7]. The $-\mathrm{NH}_{2}$ group in the $\mathrm{TCH}$ can form a $\pi-\pi$ interaction and a cation $-\pi$ bond with the benzene ring on the $\mathrm{ZnCl}_{2}$ activated bagasse-based activated carbon (ZBAC). During the pyrolysis process, cellulose and hemicellulose in bagasse (about $50 \mathrm{wt} \%$ cellulose and $25 \mathrm{wt} \%$ hemicellulose) are decomposed at $202{ }^{\circ} \mathrm{C}$ to produce levoglucosan (LGA) and anhydrosugar polymers. The isomerization reaction occurs after LGA dehydration which forms other anhydrosugars and furans [8]. The pyrolysis product is polymerized to form activated carbon at $600{ }^{\circ} \mathrm{C}$. The activated carbon produced by direct the pyrolysis of bagasse has a small specific surface area $\left(\mathrm{S}_{\mathrm{BET}}\right.$ was about $\left.376.08 \mathrm{~m}^{2} \mathrm{~g}^{-1}\right)$, and $\mathrm{ZnCl}_{2}$ helps to form more porous structures during pyrolysis $\left(\mathrm{S}_{\mathrm{BET}}\right.$ was about $831.23 \mathrm{~m}^{2} \mathrm{~g}^{-1}$ ) because $\mathrm{ZnCl}_{2}$ catalyzes the Scholl condensation reaction during pyrolysis. The above-mentioned macromolecular polycyclic compounds in bagasse form porous structures during pyrolysis at high temperatures [9].

However, how activated carbon's effect on the fate of tetracycline hydrochloride (TCH) in water has become a question demanding a quick solution, and few reports have paid attention to the adsorption and desorption behavior and mechanism. Desorption behavior influences not only the fate of $\mathrm{TCH}$ in the environment, which is still a primary concern, but also the efficient recycling of the adsorbent [10]. The structure-activity relationship of adsorbents plays a significant component in the adsorption and desorption process. The adsorption affinity between the adsorbent and the adsorbate determines adsorption and desorption behavior. In this work, adsorption and desorption performances of tetracycline hydrochloride by activated carbon derived from sugar cane bagasse activated with $\mathrm{ZnCl}_{2}$ and their mechanisms were studied.

\section{Results and Discussions}

\subsection{Materials Structure and Composition}

SEM images of bagasse, ZBAC and regenerated ZBAC ware shown in Figure 1. Figure $1 \mathrm{~b}$ shows parallel tunnel-type pore structure compared to Figure $1 \mathrm{a}$, which indicated that $\mathrm{ZnCl}_{2}$ activation and pyrolysis process contributed to the formation of a new pore structure in bagasse. This is one of the reasons why ZBAC had high-efficiency adsorption performance compared to BAC. It can be seen from Figure $1 c$ that some of the pore structure remained after desorption, which indicated that ZBAC can be reused several times. What is more, $\mathrm{S}_{\mathrm{BET}}, \mathrm{D}_{\mathrm{P}}$, and $\mathrm{V}_{\text {mic }}$ of $\mathrm{BAC}$ and ZBAC were shown in Table S1, and ZBAC had a larger $S_{B E T}$, smaller $D_{P}$, and larger $V_{\text {mic }}$ than BAC. $\mathrm{ZnCl}_{2}$ catalyzed the Scholl condensation reaction and formed a porous structure during the carbonization process [9]. No sharp peak in ZBAC was shown in the XRD pattern (Figure S1a, marked with "AC"), which revealed a predominantly amorphous structure of activated carbon in ZBAC. The broad peak was an advantageous characteristic that made bagasse suitable for the preparation of the activated carbon adsorbent [11]. The TGA/DTGA of bagasse and ZIB are shown in Figure S2. There was no obvious weight loss above $600{ }^{\circ} \mathrm{C}$ in Figure S2b, therefore $600{ }^{\circ} \mathrm{C}$ was the minimum carbonization temperature for ZIB pyrolysis to prepare ZBAC [12]. FTIR spectroscopy of bagasse, ZBAC, and TCH load ZBAC are shown in Figure S1b. The bands at 1118, 1086, and $880 \mathrm{~cm}^{-1}$ were related to C-N stretching vibrations, $\mathrm{C}-\mathrm{H}$ symmetric deformation vibrations, and $\mathrm{N}-\mathrm{H}$ deformation vibrations [13]. Comparing the spectroscopy before and after adsorption, the band at $1086 \mathrm{~cm}^{-1}$ was weakened after adsorption and new bands of $880 \mathrm{~cm}^{-1}$ appeared. The ring structure in the TCH and aromatic rings in ZBAC promoted $\pi-\pi$ interactions, and cation $-\pi$ bonding occurred between the ZBAC and the easily protonated $-\mathrm{NH}_{2}$ which was located on the ring $\mathrm{C} 4$ of the TCH. FT-IR analysis confirmed the successful combination of $\mathrm{ZBAC}$ and $\mathrm{TCH}$, indicating that bagasse was beneficial to $\mathrm{TCH}$ adsorption after $\mathrm{ZnCl}_{2}$ activation and pyrolysis [14]. 

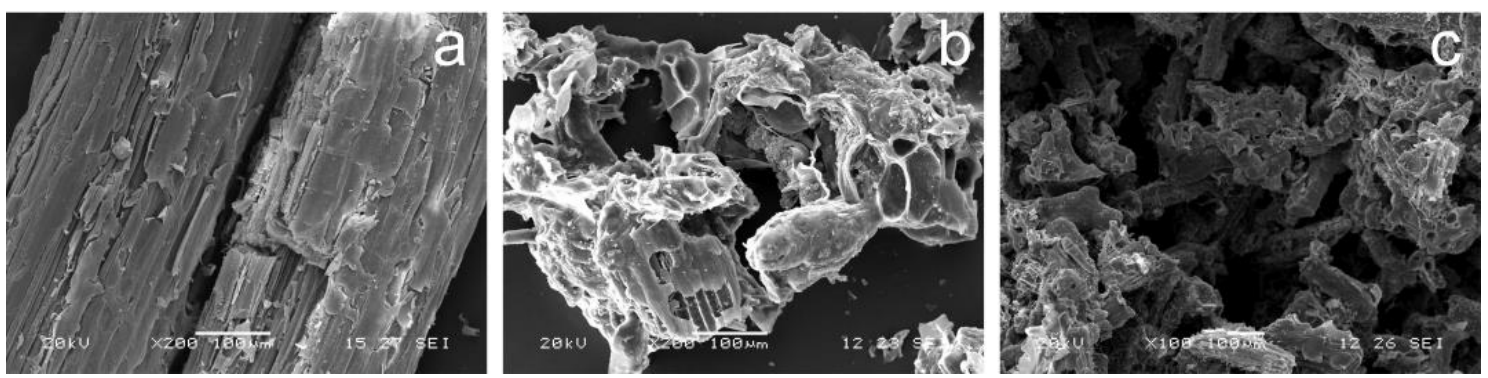

Figure 1. SEM images of (a) bagasse, (b) $\mathrm{nCl}$ activated bagasse based activated carbon (ZBAC), and (c) repeated use of ZBAC.

\subsection{Batch Adsorption Experiments}

\subsubsection{Effect of $\mathrm{pH}$}

The $\mathrm{pH}$ of the TCH solution is an important parameter for controlling the adsorption capacity of the ZBAC. The adsorption of TCH decreased from $149.4-135.3 \mathrm{mg} \mathrm{g}^{-1}$ as the $\mathrm{pH}$ increased from 2 to 10 (Figure 2a). When the $\mathrm{pH}$ continued to increase to 12 , the adsorption capacity slumped to $79.25 \mathrm{mg} \mathrm{g}^{-1}$. The adsorption efficiency was only $53 \%$ of the maximum when the $\mathrm{pH}$ was 12 . These results indicated that many of the reactive functional groups sited on the surface of the $\mathrm{ZBAC}$, such as $-\mathrm{OH}$ and $-\mathrm{COOH}$, were passivated or blocked when $\mathrm{pH}>10$. This phenomenon usually occurred during the chemisorption. Tetracycline (TC) was an amphoteric substance with different ionizable groups on the molecule surface at different $\mathrm{pH}$ values (Figure 2a insert). The dominated $\mathrm{TC}\left(\mathrm{H}_{2} \mathrm{TC}\right)$ species were $\mathrm{H}_{3} \mathrm{TC}^{+}$at $\mathrm{pH}<3.4, \mathrm{H}_{2} \mathrm{TC}$ at $\mathrm{pH}$ of 3.4-7.6, $\mathrm{HTC}^{-}$at $\mathrm{pH}$ of 7.6-9.0, and $\mathrm{TC}^{2-}$ at $\mathrm{pH}>9$ [13]. The $\mathrm{pH}_{\mathrm{pzc}}$ of ZBAC was 8.3 (Figure $2 b$ ). Thus, the electrostatic attraction between TC and ZBAC increased with the decreasing of $\mathrm{pH}$ when $\mathrm{pH}<8.3$. Correspondingly, $\mathrm{q}_{\mathrm{e}}$ of $\mathrm{ZBAC}$ decreased when $\mathrm{pH}>8.3$. This was mainly caused by the disadvantageous electrostatic conditions between $\mathrm{TC}\left(\mathrm{HTC}^{-}\right.$and/or $\mathrm{TC}^{2-}$ ) and ZBAC surfaces [15].
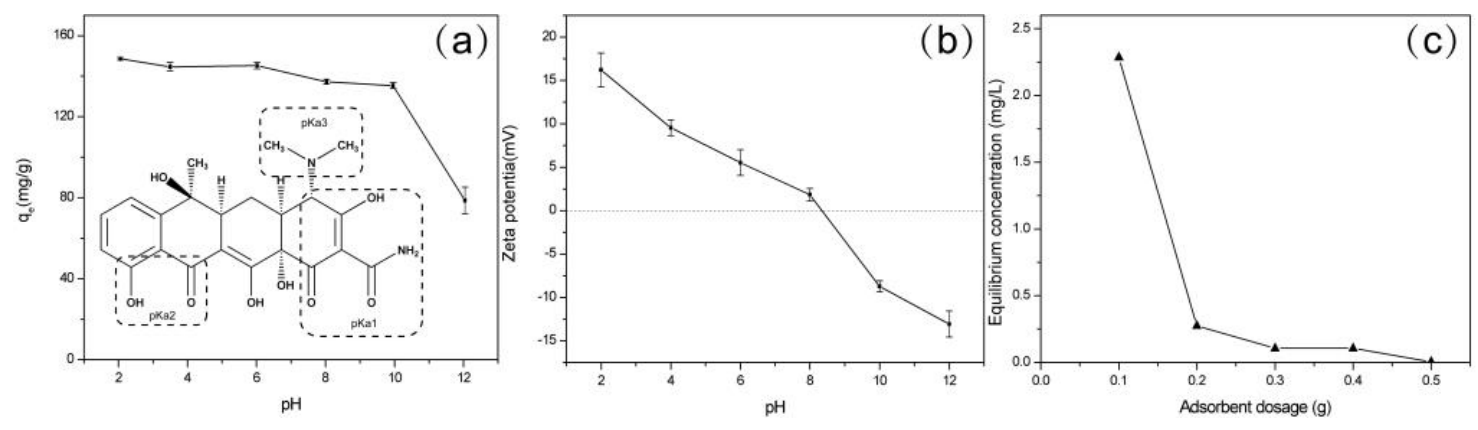

Figure 2. (a) Effect of $\mathrm{pH}\left(C_{0}=300 \mathrm{mg} \mathrm{L}^{-1}, \mathrm{~V}=50 \mathrm{~mL}, 0.1 \mathrm{~g} \mathrm{ZBAC}, \mathrm{T}=298 \mathrm{~K}\right)$; (b) Zeta potential of ZBAC as a function of $\mathrm{pH}$; (c) Effect of adsorbent dosage $\left(C_{0}=240 \mathrm{mg} \mathrm{L}^{-1}, \mathrm{~V}=100 \mathrm{~mL}, \mathrm{pH}=3.5\right.$, $\mathrm{T}=298 \mathrm{~K})$.

\subsubsection{Adsorbent Dosage Studies}

Different mass of ZBAC (0.1, 0.2, 0.3, 0.4, $0.5 \mathrm{~g})$ was added in $240 \mathrm{mg} \mathrm{L}^{-1} \mathrm{TCH}$ solutions, and the solution concentration at the equilibrium adsorption was measured (Figure $2 \mathrm{c}$ ). The $\mathrm{q}_{\mathrm{m}}$ was $119.8 \mathrm{mg} \mathrm{g}^{-1}$ when the ZBAC was $0.2 \mathrm{~g}$. The adsorption performance of ZBAC was determined and the next experiment was designed through this experiment. Table 1 listed comparison of ZBAC adsorption capacity with several kinds of bioresource-based activated carbons. 
Table 1. Comparison of tetracycline hydrochloride (TCH) adsorption ZBAC ability with other bioresource-based activated carbon reported in references.

\begin{tabular}{ccc}
\hline ACs & $\left.\mathbf{q}_{\mathbf{m}} \mathbf{~} \mathbf{m g ~}^{\mathbf{- 1}}\right)$ & References \\
\hline Human hair & 128.5 & Ahmed, et al. [16] \\
Chicken feather & 388.3 & Li, Hu, Meng, Su and Wang [13] \\
Rice-husk & 58.8 & Chen, et al. [17] \\
Bamboo charcoal & 27.7 & Liao, et al. [18] \\
Rice husk ash & 8.37 & Liu, et al. [19] \\
Sugar cane bagasse & 239.6 & This study \\
\hline
\end{tabular}

\subsubsection{Kinetics Studies}

The $\mathrm{q}_{\mathrm{t}}$ was quickly reached near to the adsorption equilibrium in $30 \mathrm{~min}$ at $298 \mathrm{~K}$ (Figure 3). Then, it took a long time $(120 \mathrm{~min})$ to rise slowly and reach adsorption at the equilibrium point, while it took only $20 \mathrm{~min}$ at $318 \mathrm{~K}$. Consequently, the time required to reach the adsorption equilibrium point was shorter as the temperature increased, which indicated that high temperature contributed to the adsorption process.

The non-linearized form of pseudo first-order kinetics model (Model I, Equation (1)) and the pseudo second-order kinetics model (Model II, Equation (2)) were used to simulate the kinetic data, as follows [20]:

$$
\begin{gathered}
\mathrm{q}_{\mathrm{t}}=\mathrm{q}_{\mathrm{e}}\left(1-\mathrm{e}^{-\mathrm{k}_{1} \mathrm{t}}\right), \\
\mathrm{q}_{\mathrm{t}}=\frac{\mathrm{q}_{\mathrm{e}}^{2} \mathrm{k}_{2} \mathrm{t}}{1+\mathrm{q}_{\mathrm{e}} \mathrm{k}_{2} \mathrm{t}}
\end{gathered}
$$

The initial adsorption rate equation (Equation (3)) [21]:

$$
\mathrm{k}_{0}=\mathrm{k}_{2} \mathrm{q}_{\mathrm{e}}^{2}
$$

The adsorption kinetics fitted better with Model II than Model I (Table S2). The $R^{2}$ of Model II $(0.9437,0.9106,0.9988)$ were higher than Model I $(0.8523,0.9481,0.9864)$. Model II was believed to fit experimental data more accurately. Therefore, the adsorption behavior of $\mathrm{TCH}$ was followed by Model II, which indicated that the adsorption process was mainly via chemisorption [22].

$\mathrm{TCH}$ could permeate from the ZBAC surface to the inner surface by intraparticle diffusion. The intraparticle diffusion model (Model ID) was evaluated with the following Equation (4) [23]:

$$
\mathrm{q}_{\mathrm{t}}=\mathrm{k}_{\mathrm{i}} \mathrm{t}^{\frac{1}{2}}+\mathrm{C}
$$

There were higher $R^{2}$ values $(0.9083,0.9426$, and 0.9136$)$ in the Model ID (Figure 4a) than Model I and Model II (Table S2). The results showed the intraparticle diffusion model could be better fitted with the adsorption process because of the porous structure of ZBAC, which was considered to be the key process of ZBAC adsorption TCH. In order to further clarify the rate-determining step and adsorption mechanism in the adsorption process, the Model ID was fitted into two sectors (Figure 4b), and the resulting parameters were shown in Table 2. In the first sector, TCH was diffused to the surface of $\mathrm{ZBAC}$ for adsorption in the liquid phase. In the second sector, $\mathrm{TCH}$ was gradually adsorbed on ZBAC, where intraparticle diffusion played a leading role in this sector. The slopes of the two sectors obtained through calculation were different. The slope of the first sector $(1.073,1.250$, and 2.079) were much higher than the slope of the second sectors $(0.3948,0.5875$, and 0.7908$)$, indicating that the surface adsorption rate in the first sector was faster than the gradual adsorption rate in the second sector and intraparticle diffusion was not the only rate-determining step. The entire adsorption process was complex, which was determined by surface adsorption and intraparticle diffusion. 

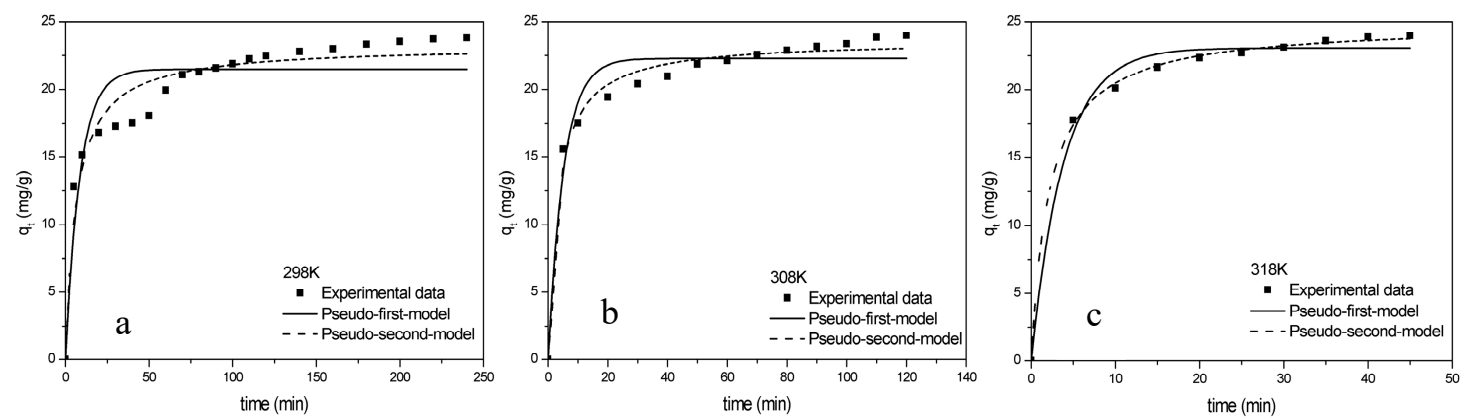

Figure 3. The Model I and Model II of TCH onto ZBAC (a) $298 \mathrm{~K}$; (b) $308 \mathrm{~K}$; (c) $318 \mathrm{~K}\left(C_{0}=120 \mathrm{mg} \mathrm{L}^{-1}\right.$, $\mathrm{pH}=6, \mathrm{~V}=100 \mathrm{~mL}, \mathrm{ZBAC}=0.5 \mathrm{~g})$.
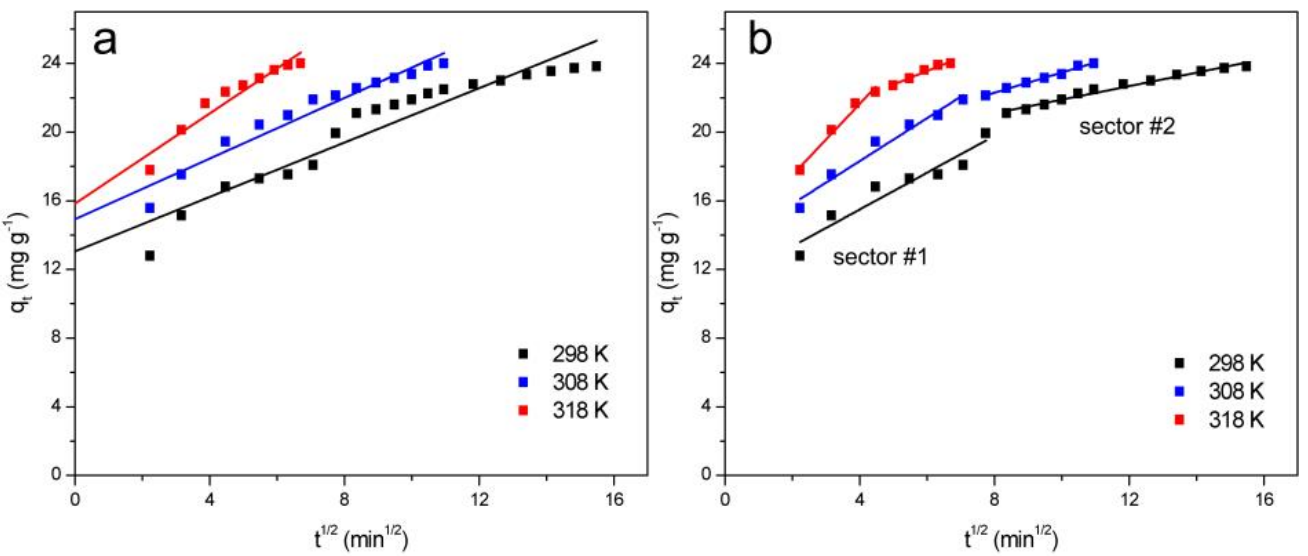

Figure 4. Intraparticle diffusion models of TCH onto ZBAC (a) overall fitting; (b) Two-sector fitting.

Table 2. Model ID Parameters of TCH Removal onto ZBAC (two-sector).

\begin{tabular}{|c|c|c|c|c|}
\hline Model ID & $q_{e, \exp } \mathbf{m g ~ g}^{-1}$ & $k_{i} \mathrm{mg}^{-1} \mathrm{~g} \mathrm{~min}^{-1 / 2}$ & $C \mathrm{mg} \mathrm{g}^{-1}$ & $R^{2}$ \\
\hline & \multicolumn{4}{|c|}{ Sector \#1 } \\
\hline $298 \mathrm{~K}$ & 19.938 & 1.073 & 17.938 & 0.9013 \\
\hline $308 \mathrm{~K}$ & 21.885 & 1.250 & 13.310 & 0.9629 \\
\hline \multirow[t]{2}{*}{$318 \mathrm{~K}$} & 22.335 & 2.079 & 13.330 & 0.9696 \\
\hline & \multicolumn{4}{|c|}{ Sector \#2 } \\
\hline $298 \mathrm{~K}$ & 23.818 & 0.3948 & 17.938 & 0.9743 \\
\hline $308 \mathrm{~K}$ & 23.999 & 0.5875 & 17.593 & 0.9891 \\
\hline $318 \mathrm{~K}$ & 23.999 & 0.7908 & 18.812 & 0.9571 \\
\hline
\end{tabular}

\subsubsection{Adsorption Isotherm}

Three adsorption models were utilized to study the adsorption performance: Langmuir, Freundlich and Dubinin-Radushkevich isotherm models. Langmuir isotherm model (Model L) was a monolayer adsorption process with uniform distribution of adsorbates without any interaction [24]. The Langmuir isotherm was (Equation (5)) [23]:

$$
\frac{c_{e}}{q_{e}}=\frac{1}{q_{0} k}+\frac{c_{e}}{q_{0}}
$$

The dimensionless constant separation factor $\left(R_{L}\right)$ could be used to judge whether the adsorption process was favorable for the Model L. The $R_{L}$ calculating equation was as follows (Equation (6)) [25]:

$$
R_{L}=\frac{1}{1+\mathrm{Kc}_{0}}
$$


The value of $R_{L}$ was calculated to range from 0.001 to 0.022 (Table S3). As listed above, proving porous structure contributed to adsorption because the $R_{L}$ was not only in the range of $0-1$ but also much less than 1.

While the Freundlich isotherm model (Model F) was multilayer adsorption, as followings (Equation (7)) [26]:

$$
\ln \mathrm{q}_{\mathrm{e}}=\ln \mathrm{k}_{\mathrm{f}}+\frac{1}{\mathrm{n}} \ln \mathrm{c}_{\mathrm{e}}
$$

The value of $1 / \mathrm{n}$ was calculated to range from 0.007 to 0.538 (Table S4), which between $0-1$, suggesting that TCH could be easily adsorbed on the ZBAC [27]. The adsorption isotherm curve and the fit curve were shown in Figure 5. Because the $R^{2}$ for TCH obtained from Model F $(0.9048,0.9070$, and 0.9922$)$ were higher than Model L $(0.8011,0.9499$, and 0.9830$)$, Model F could exactly match the experimental data in both models. The $\mathrm{k}_{\mathrm{f}}$ (Freundlich constants) calculated from the Model $\mathrm{F}$ were $73.82,148.9$, and 276.7, which indicated that physisorption and chemisorption together constituted the adsorption process of ZBAC adsorption TCH [28].

Dubinin-Radushkevich isotherm model (Model DR) could be used to predict adsorption energy, as follows (Equation (8)) [29]:

$$
\ln \mathrm{q}_{\mathrm{e}}=\ln \mathrm{q}_{\mathrm{m}}-\varepsilon^{2}
$$

$K^{\prime}\left(E, \mathrm{~kJ} \mathrm{~mol}^{-1}\right)$ was related to express the adsorption energy (Equation (9)):

$$
\mathrm{E}=\frac{1}{\left(2 K^{\prime}\right)^{\frac{1}{2}}}
$$

Adsorption energy calculated from the figure of $\ln q_{e}$ versus $E$ were listed in Table $S 4$. The adsorption process could be regarded as chemisorption when $E>8 \mathrm{~kJ} \mathrm{~mol}^{-1}$, which was in the range of $13.51 \sim 17.96 \mathrm{~kJ} \mathrm{~mol}^{-1}$ in this study. It was also found that the adsorption process had a high correlation with the Model ID $(0.9068,0.9961$, and 0.9907). Therefore, the adsorption process in this study was closely related to chemisorption.

The type of adsorption can be decided by some thermodynamic parameters, such as Gibbs free energy $(\Delta G) . \Delta G$ is calculated as follows (Equation (10)):

$$
\Delta \mathrm{G}=-\mathrm{RT} \ln \mathrm{K}
$$

where $\mathrm{K}$ represents the adsorption equilibrium constant (from Langmuir model). The calculated $\Delta \mathrm{G}$ under $298 \mathrm{~K}, 308 \mathrm{~K}$, and $318 \mathrm{~K}$ were $1.827,0.275$, and $-1.014 \mathrm{KJ} \mathrm{mol}^{-1}$ respectively. It can be seen that $\Delta \mathrm{G}$ decreased with increasing temperature, from less than 0 to greater than 0 , which indicated that the adsorption process of ZBAC was feasible and spontaneous thermodynamically when temperature increased. This was why initial rate of the adsorption capacity increase with increasing of the temperature.
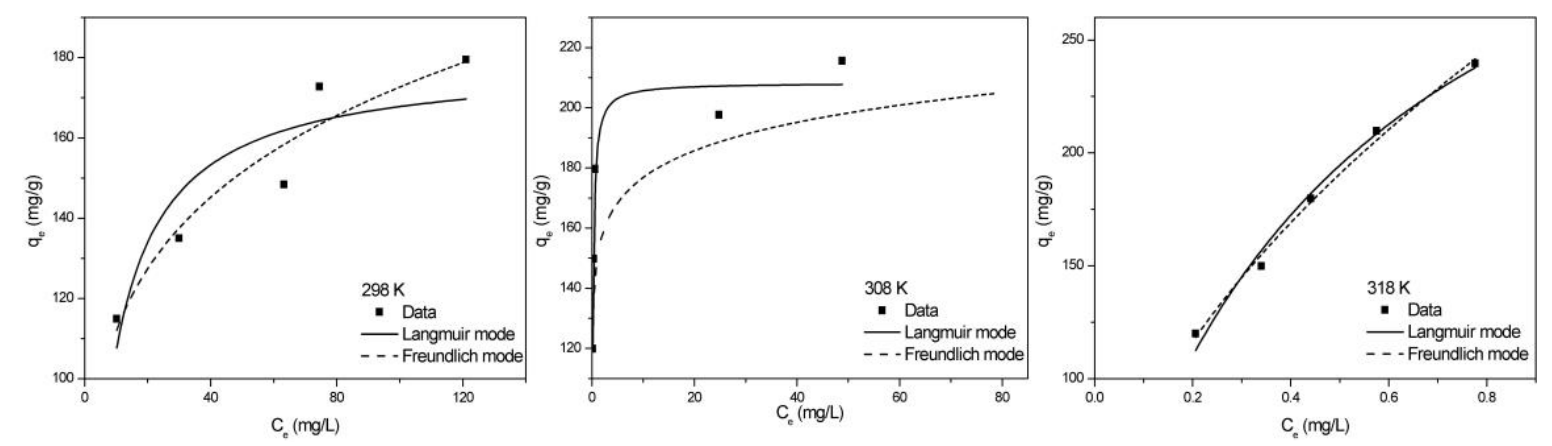

Figure 5. Adsorption equilibrium isotherm of TCH onto ZBAC: Model L and Model F fitting curve. $\left(C_{0}=240,300,360,420,480 \mathrm{mg} \mathrm{L}^{-1}, \mathrm{pH}=3.5, \mathrm{~V}=50 \mathrm{~mL}, \mathrm{ZBAC}=0.1 \mathrm{~g}\right)$. 


\subsection{Fixed Bed Adsorption Experiments}

Define the following parameters according to the previous research: the breakthrough point is $C_{t} / C_{0}=10 \%$, and saturation point is $C_{t} / C_{0}=90 \%$ [30]. These parameters of fixed bed adsorption were summarized in Table 3. The calculation methods for empty bed contact time (EBCT, Equation (11)) and mass transfer zone (MTZ, Equation (12)) were [30]:

$$
\begin{aligned}
\mathrm{EBCT} & =\frac{\text { Bed volume }}{\text { Flow rate }} \\
\mathrm{MTZ} & =H\left(1-\frac{t_{b}}{t_{s}}\right)
\end{aligned}
$$

\subsubsection{Effect of Flow Rate}

The experimental data under various $Q$ were shown in Figure 6a. It had been observed the breakthrough curve had a steeper slope, and $t_{b}$ became shorter when $Q$ increased. The slower $Q$ provided a longer time for TCH to occupy the adsorption site on ZBAC. Accelerating flow rate contributed to the promotion of the mass transfer rate, while the adsorption capacity of ZBAC was not significantly reduced [18].
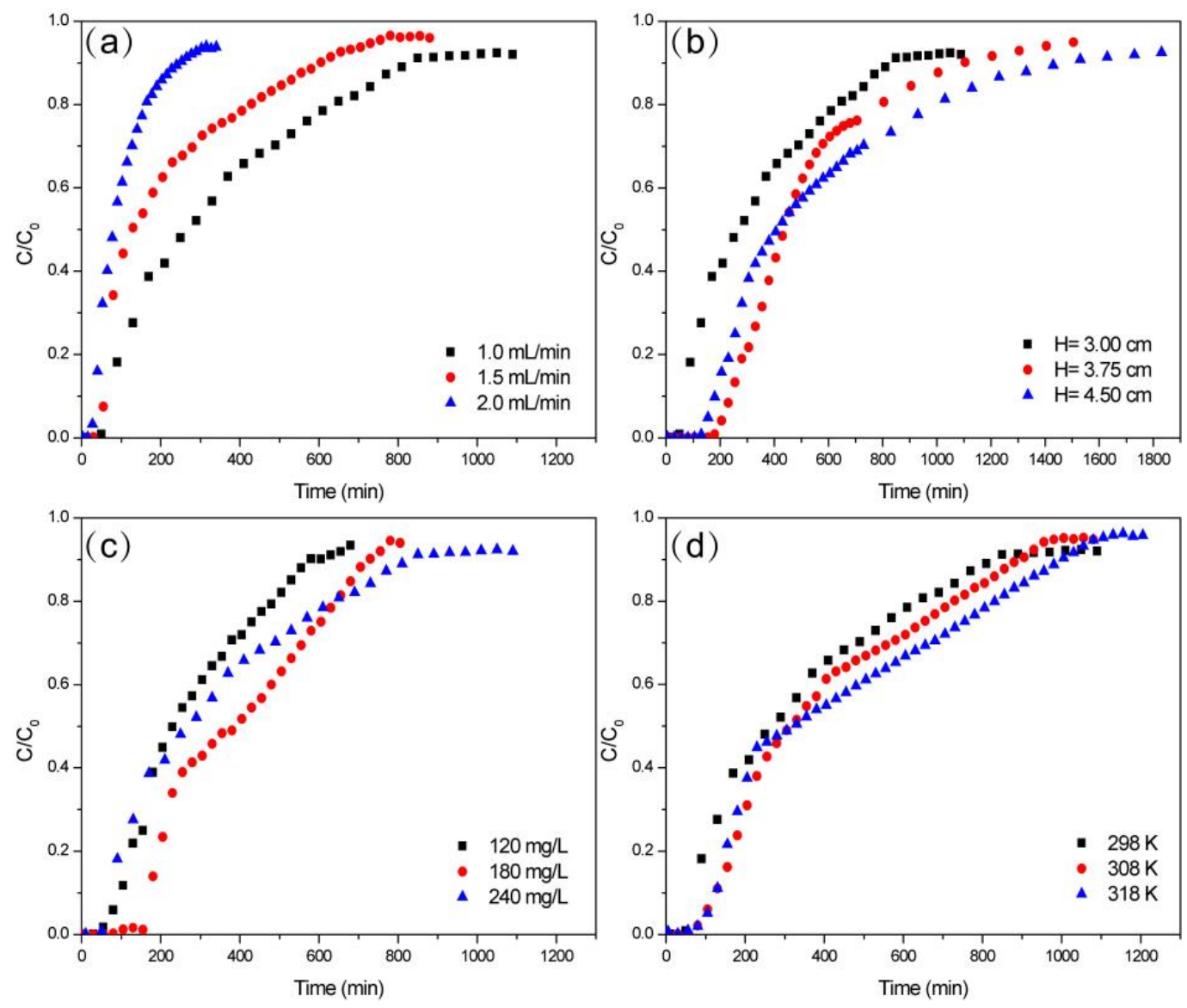

Figure 6. Breakthrough curves of TCH adsorption by ZBAC using fixed-bed columns of (a) different flow rates $\left(\mathrm{C}_{0}=240 \mathrm{mg} \mathrm{L}^{-1}, \mathrm{H}=3 \mathrm{~cm}, \mathrm{pH}=3.5, \mathrm{~T}=298 \mathrm{~K}\right)$, (b) different bed height $\left(\mathrm{Q}=1.0 \mathrm{~mL} \mathrm{~min}^{-1}\right.$, $\left.\mathrm{C}_{0}=240 \mathrm{mg} \mathrm{L}^{-1}, \mathrm{pH}=3.5, \mathrm{~T}=298 \mathrm{~K}\right)$, (c) different initial concentrations $(\mathrm{Q}=1.0 \mathrm{~mL} \mathrm{~min}-1, \mathrm{H}=3 \mathrm{~cm}$, $\mathrm{pH}=3.5, \mathrm{~T}=298 \mathrm{~K})$, and $(\mathrm{d})$ different temperature $\left(\mathrm{Q}=1.0 \mathrm{~mL} \mathrm{~min}^{-1}, \mathrm{C}_{0}=240 \mathrm{mg} \mathrm{L}^{-1}, \mathrm{H}=3 \mathrm{~cm}\right.$, $\mathrm{pH}=3.5)$. 
Table 3. Breakthrough curve parameters for adsorption of TCH onto ZBAC.

\begin{tabular}{|c|c|c|c|c|c|c|c|c|c|c|c|c|c|c|c|c|c|}
\hline No. & $\begin{array}{c}\mathrm{mL} / \mathrm{min} \\
\mathrm{Q}\end{array}$ & $\begin{array}{c}\mathrm{cm} \\
H\end{array}$ & $\begin{array}{l}\mathrm{K} \\
T\end{array}$ & $\begin{array}{c}\mathrm{mg} / \mathrm{L} \\
C_{0}\end{array}$ & $\mathrm{pH}$ & $\min _{t_{b}}$ & $\begin{array}{c}\mathrm{mL} \\
V_{b}\end{array}$ & $\begin{array}{c}\mathrm{mg} / \mathrm{g} \\
\mathrm{q}_{\mathrm{b}}\end{array}$ & $\begin{array}{c}\% \\
R_{b}\end{array}$ & $\min _{t_{s}}$ & $\begin{array}{c}\mathrm{mL} \\
V_{s}\end{array}$ & $\begin{array}{c}\mathrm{mg} / \mathrm{g} \\
\mathrm{q}_{\mathrm{s}}\end{array}$ & $\begin{array}{c}\% \\
R_{S}\end{array}$ & $\stackrel{\mathrm{g}}{M}$ & $\underset{\mathrm{mg} / \mathrm{L}}{C_{e}}$ & $\begin{array}{c}\min \\
\text { EBTC }\end{array}$ & $\begin{array}{c}\text { cm } \\
\text { MTZ }\end{array}$ \\
\hline 1 & 1 & 3 & 298 & 120 & 3.5 & 105 & 105 & 15.24 & 96.77 & 580 & 580 & 42.07 & 49.21 & 0.8 & 112.8 & 2.85 & 2.46 \\
\hline 2 & 1 & 3 & 298 & 180 & 3.5 & 180 & 180 & 39.87 & 98.45 & 730 & 730 & 91.73 & 55.84 & 0.8 & 169.2 & 2.85 & 2.26 \\
\hline 3 & 1 & 3 & 298 & 240 & 3.5 & 70 & 70 & 14.94 & 99.63 & 850 & 850 & 105.3 & 41.3 & 0.8 & 227.5 & 2.85 & 2.75 \\
\hline 4 & 1 & 3.75 & 298 & 240 & 3.5 & 230 & 230 & 54.62 & 98.95 & 1105 & 1105 & 126.4 & 47.67 & 1 & 236.5 & 3.56 & 2.97 \\
\hline 5 & 1 & 4.5 & 298 & 240 & 3.5 & 180 & 180 & 35.46 & 98.51 & 1530 & 1530 & 118.9 & 38.88 & 1.2 & 237.8 & 4.27 & 3.97 \\
\hline 6 & 1.5 & 3 & 298 & 240 & 3.5 & 55 & 82.5 & 24.03 & 98.23 & 605 & 907.5 & 100.1 & 46.77 & 0.8 & 230.4 & 1.9 & 2.73 \\
\hline 7 & 2 & 3 & 298 & 240 & 3.5 & 40 & 80 & 23.15 & 96.45 & 240 & 480 & 61.55 & 42.75 & 0.8 & 225.2 & 1.43 & 2.5 \\
\hline 8 & 1 & 3 & 308 & 240 & 3.5 & 130 & 130 & 37.95 & 97.31 & 905 & 905 & 123.5 & 45.5 & 0.8 & 232.8 & 2.85 & 2.57 \\
\hline 9 & 1 & 3 & 318 & 240 & 3.5 & 130 & 130 & 37.94 & 97.34 & 1005 & 1005 & 134.9 & 44.5 & 0.8 & 238.8 & 2.85 & 2.61 \\
\hline
\end{tabular}




\subsubsection{Effect of Bed Height}

The experimental data under various $H$ were shown in Figure $6 \mathrm{~b}$. The increase in fixed bed height meant more mass of ZBAC and more longitudinal distribution. Diffusion of TCH into the ZBAC increases with the higher bed. It could conclude that $t_{s}$ increased significantly when $H$ heightened. The higher $H$ represented a longer EBCT, a wider mass transfer zone, and a lower slope during the adsorption process [31].

\subsubsection{Effect of Initial Concentration}

The experimental data under various $C_{0}$ were shown in Figure 6c. It provided a stronger driving force when the $\mathrm{C}_{0}$ of TCH increased [32]. Higher $\mathrm{C}_{0}$ of TCH provided more $\mathrm{TCH}$ to bind to the adsorption site of ZBAC, which might be the reason for an increase in adsorption capacity. The adsorption procedure required more time to reach the equilibrium due to the $\mathrm{C}_{0}$ of TCH increased, so the saturation time increased and the slope decreased.

\subsubsection{Effect of Temperature}

The experimental data under various temperatures were shown in Figure 6d. It provided a stronger driving force and equilibrium concentration was closer to the initial concentration when the temperature rose. This result was consistent with the kinetic study that high temperatures accelerated the absorbed velocity and adsorption could reach equilibrium point quickly.

\subsubsection{Modelling of Breakthrough Curves}

The calculated parameters of the six models at various experimental conditions are listed in Table 4. The equations for the six models are listed in Table S5 [30]. The $R^{2}$ of five of the models (except the Clark model) ranged from 0.9228 to 0.9966 . The $R^{2}$ of the Clark model was calculated to fall between 0.8374 and 0.9246 . This indicated well-fitting results between the experimental data and the fixed bed data generated from these models. Consequently, the Dose Response model was believed a fitting model for ZBAC adsorption of TCH because it had the highest $R^{2}$ amongst all models.

The $\mathrm{q}_{0}$ rose when $C_{0}$ increased in the Dose Response and Thomas model, which was consistent with the actual experimental data. Moreover, $\mathrm{q}_{0}$ rose as $H$ increased in those two models, which may be attributed to an increase in the residence time of the TCH and an increase in the ZBAC mass. Similar results were found in the Adams-Bohart and BDST models, and as $C_{0}$ rose, volumetric adsorption capacity decreased [33]. $\tau$ in the Yoon-Nelson model indicated the time required to reach $50 \%$ retentions. $\tau$ reduced obviously as $Q$ increases because the adsorption in the fixed bed reached saturation at a higher value of $Q$ and the calculated value of $\tau$ was consistent with the experimental data.

\subsection{Fixed Bed Desorption Experiments}

TCH (240 $\left.\mathrm{mg} \mathrm{L}^{-1}\right)$ loaded ZBAC was desorbed by anhydrous alcohol which was regarded as eluent [34]. Ethanol provided hydrogen bonds that bound to hydrogen bond acceptors on the TCH for separating the TCH from the adsorbent active sites on the ZBAC. The elution curve was similar to the breakthrough curve, while referred to the desorption process. It was observed from Figure 7 that the elution curve had an asymmetrical distribution shape, and the released TCH concentration rapidly increased at the initial stage, followed by decreasing to a flat state. 
Table 4. Six models parameters at different conducted conditions.

\begin{tabular}{|c|c|c|c|c|c|c|c|c|c|c|}
\hline Model & Parameters & 1 & 2 & 3 & 4 & 5 & 6 & 7 & 8 & 9 \\
\hline \multirow[t]{3}{*}{ Adams-Bohart } & $K_{A B}\left(\mathrm{~L} \mathrm{mg}^{-1} \mathrm{~min}^{-1}\right) \times 10^{-5}$ & 6.951 & 3.684 & 2.126 & 1.406 & 3.137 & 3.008 & 9.307 & 2.143 & 1.710 \\
\hline & $N_{0}\left(\mathrm{mg} \mathrm{L}^{-1}\right) \times 10^{4}$ & 0.932 & 2.041 & 2.367 & 2.293 & 2.469 & 2.154 & 1.300 & 2.692 & 2.984 \\
\hline & $R^{2}$ & 0.958 & 0.955 & 0.9459 & 0.966 & 0.9659 & 0.937 & 0.945 & 0.945 & 0.928 \\
\hline \multirow[t]{3}{*}{ Thomas } & $K_{t h}\left(\mathrm{~L} \mathrm{mg}^{-1} \min ^{-1}\right) \times 10^{-5}$ & 6.967 & 3.685 & 2.071 & 1.969 & 3.137 & 3.002 & 9.309 & 2.164 & 1.694 \\
\hline & $q_{0}\left(\mathrm{mg} \mathrm{g}^{-1}\right)$ & 41.13 & 91.69 & 97.15 & 97.43 & 112.6 & 84.77 & 56.72 & 115.2 & 126.4 \\
\hline & $R^{2}$ & 0.958 & 0.955 & 0.9412 & 0.923 & 0.9659 & 0.938 & 0.946 & 0.945 & 0.928 \\
\hline \multirow[t]{3}{*}{ Yoon-Nelson } & $K_{Y N}\left(\min ^{-1}\right) \times 10^{-2}$ & 0.836 & 0.675 & 0.502 & 0.472 & 0.753 & 0.720 & 2.234 & 0.520 & 0.411 \\
\hline & $\tau_{c a l}(\min )$ & 274.1 & 403.5 & 320.6 & 487.1 & 469.4 & 188.4 & 94.53 & 384.2 & 417.0 \\
\hline & $R^{2}$ & 0.958 & 0.955 & 0.9412 & 0.964 & 0.9659 & 0.938 & 0.945 & 0.945 & 0.928 \\
\hline \multirow[t]{3}{*}{ BDST } & $K_{B D S T}\left(\mathrm{~L} \mathrm{mg}^{-1} \mathrm{~min}^{-1}\right) \times 10^{-5}$ & 6.967 & 3.727 & 2.072 & 1.969 & 3.137 & 3.002 & 9.309 & 2.164 & 1.711 \\
\hline & $N_{0}\left(\mathrm{mg} \mathrm{L}^{-1}\right) \times 10^{4}$ & 0.894 & 1.974 & 2.112 & 2.118 & 2.449 & 1.843 & 0.616 & 25.06 & 2.720 \\
\hline & $R^{2}$ & 0.958 & 0.955 & 0.9412 & 0.923 & 0.9659 & 0.937 & 0.945 & 0.945 & 0.928 \\
\hline \multirow[t]{3}{*}{ Dose Response } & $q_{0}\left(\mathrm{mg} \mathrm{g}^{-1}\right)$ & 36.68 & 78.25 & 82.15 & 89.09 & 108.9 & 66.66 & 49.28 & 98.66 & 103.4 \\
\hline & $\alpha$ & 2.166 & 2.421 & 1.618 & 1.892 & 3.025 & 1.519 & 2.037 & 1.947 & 1.668 \\
\hline & $R^{2}$ & 0.9940 & 0.974 & 0.9906 & 0.99 & 0.9934 & 0.98 & 0.997 & 0.988 & 0.968 \\
\hline \multirow[t]{3}{*}{ Clark } & $A^{*} 10^{3}$ & 3.922 & 14.13 & 0.617 & 7.736 & 2.076 & 0.281 & 3.323 & 1.581 & 2.087 \\
\hline & $r\left(\min ^{-1}\right) \times 10^{-2}$ & 1.764 & 1.492 & 0.981 & 1.152 & 1.869 & 1.302 & 4.995 & 1.036 & 0.956 \\
\hline & $R^{2}$ & 0.902 & 0.918 & 0.8841 & 0.868 & 0.9246 & 0.837 & 0.89 & 0.884 & 0.882 \\
\hline
\end{tabular}


Experimental breakthrough curves were used to calculate the amount of $\mathrm{TCH}$ desorbed per mass of ZBAC, as follows [35]:

$$
\mathrm{q}_{\text {total,d }}=\frac{\mathrm{Q}}{1000} \int_{\mathrm{t}=0}^{\mathrm{t}=\mathrm{t}_{\text {total, }}} \mathrm{C}_{\mathrm{f}} \mathrm{dt}
$$

The amount of $\mathrm{TCH}$ desorbed, $\mathrm{q}_{\mathrm{e}, \mathrm{d}}$, through the following equation:

$$
\mathrm{q}_{\mathrm{e}, \mathrm{d}}=\frac{\mathrm{q}_{\mathrm{total}, \mathrm{d}}}{\mathrm{M}}
$$

Desorption parameters were summarized in Table 5. Although the maximum concentration $\left(C_{p}\right)$ could be reached quickly when the flow rate was increased, the total adsorption process concentration factor $\left(C F_{p}=C_{p} / 240\right)$ and desorption efficiency were decreased, which did not contribute to desorption [36]. It could be observed that the value of $C F_{p}$ was not high because the eluent was not completely effective and part of the TCH remained at the adsorbent site of the ZBAC. Consequently, this remained part of the TCH in desorption was considered to be irreversible adsorption. Comparing $C_{p}$ with $240 \mathrm{mg} \mathrm{L}^{-1}$, it was speculated that ZBAC can be recycled 2-3 times.

Table 5. Desorption parameters for adsorption-desorption cycles, using a fixed-bed column for the removal of TCH $(240 \mathrm{mg} / \mathrm{L})$ by anhydrous alcohol-treated ZBAC $(0.8 \mathrm{~g})$ at different flow rate.

\begin{tabular}{cccccc}
\hline $\mathbf{Q}$ & $\mathbf{q}_{\text {total,d }}$ & $\mathbf{q}_{\mathbf{e}, \mathbf{d}}$ & $\mathbf{t}_{\mathbf{p}}$ & $\boldsymbol{C}_{\boldsymbol{p}}$ & \multirow{2}{*}{$\boldsymbol{C F}_{\boldsymbol{p}}$} \\
\cline { 1 - 5 } $\mathbf{m L} / \mathbf{m i n}$ & $\mathbf{m g} / \mathbf{g}$ & $\mathbf{m g} / \mathbf{g}$ & $\mathbf{m i n}$ & $\mathbf{m g} / \mathbf{L}$ & \\
\hline 1.0 & 10.54 & 13.18 & 20 & 117.5 & 0.489 \\
1.5 & 5.276 & 6.595 & 15 & 58.50 & 0.244 \\
2.0 & 4.479 & 5.599 & 10 & 16.31 & 0.068 \\
\hline
\end{tabular}

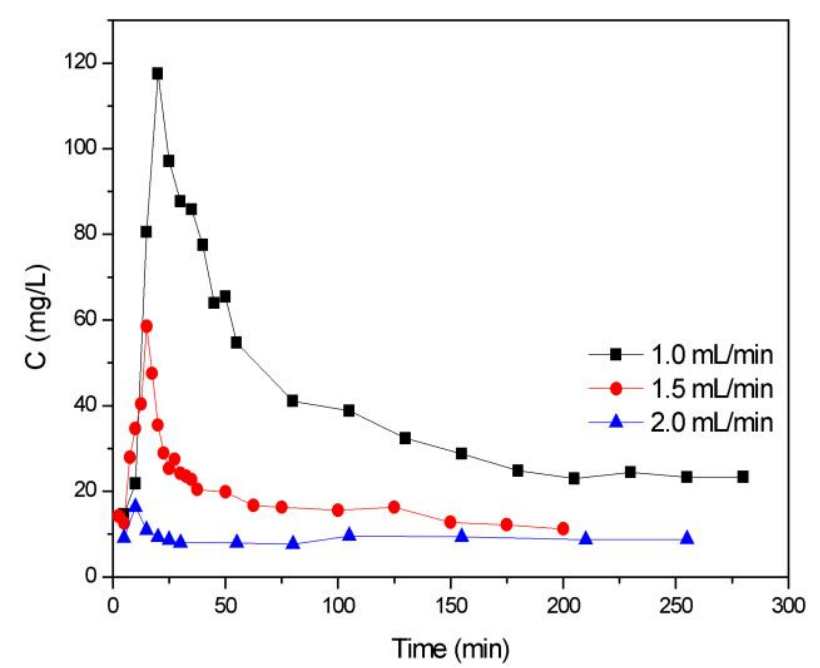

Figure 7. Elution curves for desorption of TCH from ZBAC by using anhydrous alcohol at different flow rates.

\subsection{XPS Analysis}

XPS analysis helps to further study the adsorption mechanism. Broadbands at 284.68, 286.30, and $287.82 \mathrm{eV}$ in Figure $8 \mathrm{a}$ corresponded to $\mathrm{C}=\mathrm{C}-\mathrm{C}, \mathrm{C}-\mathrm{OH}$, and $\mathrm{C}-\mathrm{O}$ bonds in bagasse, respectively. Two bands at 531.10 and $532.55 \mathrm{eV}$ in Figure $8 \mathrm{~b}$ represented $\mathrm{O}-\mathrm{H}$ and $\mathrm{C}-\mathrm{O}$ in phenols, separately [37]. The $\mathrm{C} 1 \mathrm{~s}$ spectrum of ZBAC (Figure 8c) was resolved into three individual component bands: $\mathrm{C}=\mathrm{C}$ $(284.37 \mathrm{eV}), \mathrm{C}-\mathrm{OH}(286.04 \mathrm{eV})$, and -COOR $(288.90 \mathrm{eV})$. In the N1s of TCH loaded ZBAC spectrum, the bands at 399.60 and $401.96 \mathrm{eV}$ correspond to N-H and C-N bonds, separately [38]. This also proved that TCH was successfully adsorbed onto the ZBAC. Comparing the C1s spectra of ZBAC-and 
TCH-loaded ZBAC, no difference was found in the functional group types, but the proportion slightly changed after adsorption. Lots of oxygen-containing groups were produced on the $\mathrm{ZBAC}$ after $\mathrm{ZnCl}_{2}$ activation and pyrolysis, such as $-\mathrm{OH}$ and $-\mathrm{COOH}$, which might be involved in the adsorption of the $\mathrm{TCH}$. The $\mathrm{pH}$ of the TCH in aqueous solution was 3.5, thus TCH existed in the cation form and acted as a $\pi$-electron-acceptor in the sorption process. In addition, some oxygen-containing groups on the ZBAC surface served as electron-donating groups [15]. Considering four aromatic rings in TC, the cation- $\pi$ bonding might be one of the adsorption mechanisms [3]. In this study, cation $-\pi$ bonding occurred between $\mathrm{ZBAC}$ and $-\mathrm{NH}_{2}$. The group of $-\mathrm{NH}_{2}$ which was located on the ring $\mathrm{C} 4$ of the TC could be easily protonated. The activated carbon was prepared by $\mathrm{ZnCl}_{2}$ activated bagasse and then pyrolysed, which provided many sites for adsorption, improving the adsorption capacity of $\mathrm{TCH}$ [15]. N-H on $\mathrm{TCH}$ bound to ethanol as a hydrogen bond acceptor after adsorption of TCH by ZBAC. Therefore, it could be speculated that hydrogen bonding of $\mathrm{TCH}$ and ethanol was the desorption mechanism of ZABC.
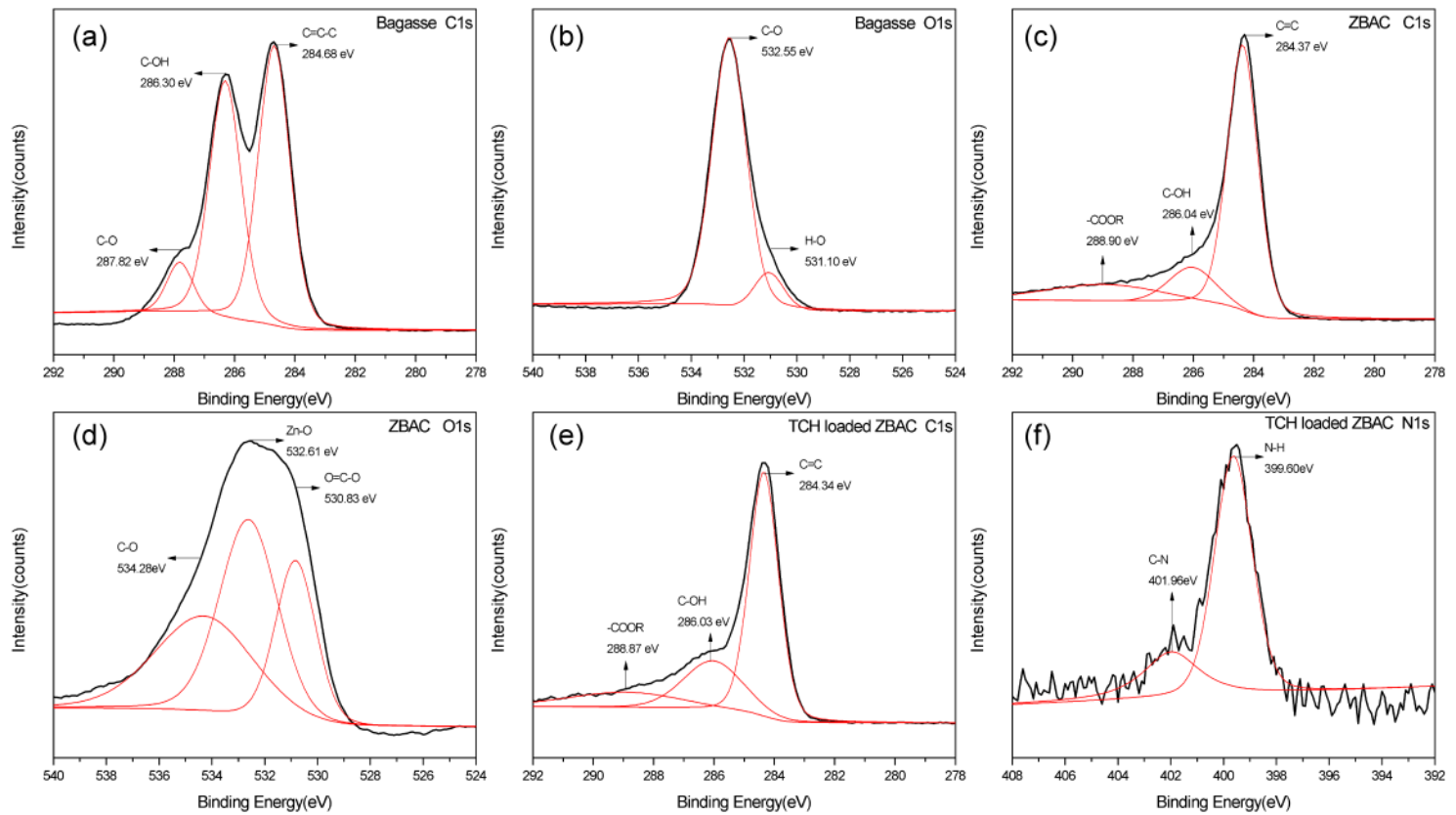

Figure 8. XPS spectra of bagasse and ZBAC: (a) C1s of bagasse, (b) O1s of bagasse, (c) C1s of ZBAC, (d) O1s of ZBAC, (e) C1s of TCH loaded ZBAC, and (f) N1s of TCH loaded ZBAC.

\subsection{Adsorption and Desorption Mechanism}

There were two main adsorption mechanisms involved between $\mathrm{ZBAC}$ and $\mathrm{TCH}$. They were intraparticle diffusion and chemisorption:

(a) The $R^{2}$ of Model ID were $0.9083,0.9426$, and 0.9136 when the temperature was in the range of 298-318K, respectively. The higher $R^{2}$ indicated that the TCH adsorption process on ZBAC fitted well with the intraparticle diffusion model, which was a vital process in the adsorption.

(b) The $\mathrm{pH}$ of $\mathrm{TCH}$ in aqueous solution was 3.5. The form of $\mathrm{TCH}$ was cation, acting as $\pi$-electron acceptor. The ZBAC surface had some oxygen-containing groups, such as $-\mathrm{OH}$ and $-\mathrm{COOH}$, which served as electron-donating groups. It was speculated that ring structure in $\mathrm{TCH}$ and aromatic ring in ZBAC promote $\pi-\pi$ interaction in them. Cation $-\pi$ bonding occurred between the ZBAC and the easily protonated $-\mathrm{NH}_{2}$ which located on the ring $\mathrm{C} 4$ of the TCH. The adsorption mechanism was illustrated in Figure 9. There were two forms of existence of $\pi-\pi$ interaction: Offset face-to-face and edge-to-face.

The desorption mechanism explained the procedure of elution of TCH on ZBAC by anhydrous ethanol. Ethanol was aprotic solvent that binds to 10 hydrogen bond acceptors in TCH, making TCH slightly soluble in ethanol. Figure 7 showed that a slower flow rate of TCH resulted in a higher 
desorption capacity, helping the TCH to separate from the ZBAC. However, the $C F_{p}$ value was low, indicating that the hydrogen bonding was insufficient to separate all of the $\mathrm{TCH}$ from the ZBAC. Therefore, this part of TCH that could not be desorbed was irreversible adsorption on ZBAC, which also indicated that ZBAC was relatively difficult to desorb while having higher adsorption capacity.

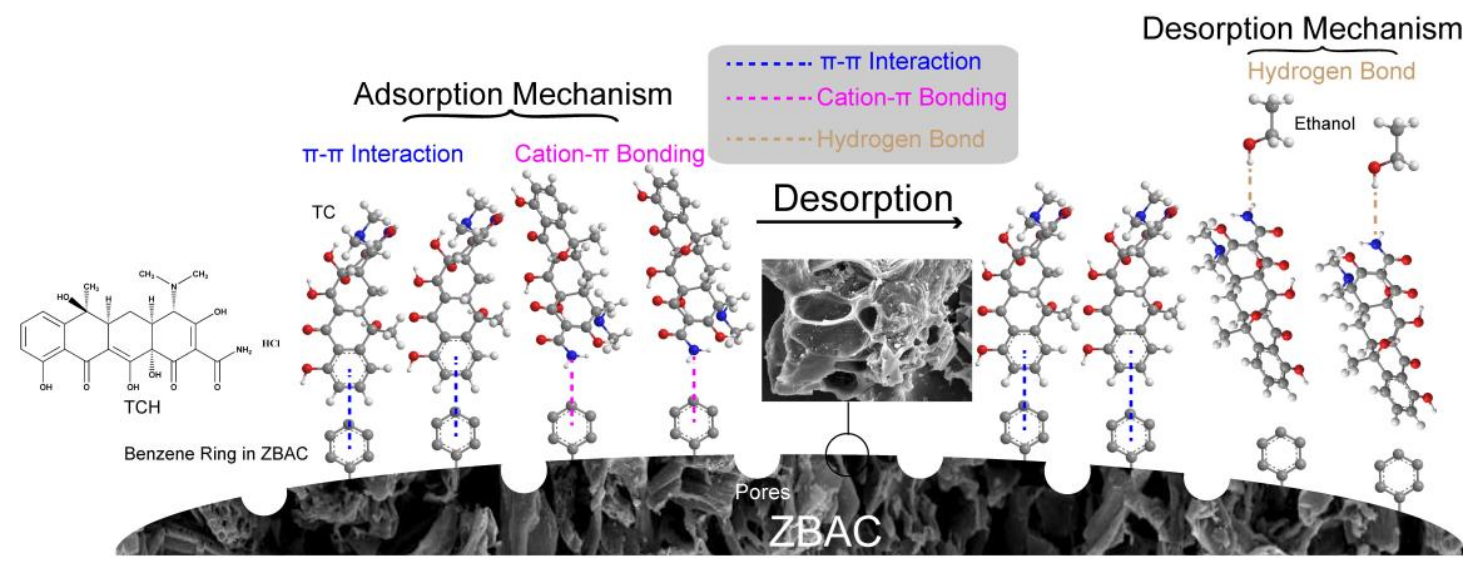

Figure 9. The schematic diagram illustrated the TCH adsorption and desorption mechanism on ZBAC.

\section{Materials and Methods}

\subsection{Materials}

The bagasse was collected by Guangdong (China) Sugarcane Industry Research Institute. $\mathrm{ZnCl}_{2}$ ( $\geq 97 \%), \mathrm{HCl}(37 \%), \mathrm{NaOH}(\geq 96 \%)$, and anhydrous alcohol $(\geq 99.5 \%)$ were purchased from the Chinese market. Tetracycline hydrochloride (USP) was purchased from Aladdin Industrial Corporation (Shanghai, China).

\subsection{Preparation of the Absorbents}

The preparation of the adsorbent in this study involved a two-step process: (1) impregnation of pre-carbonization bagasse with $\mathrm{ZnCl}_{2}$, followed by (2) pyrolysis with nitrogen at $600{ }^{\circ} \mathrm{C}\left(10^{\circ} \mathrm{C} / \mathrm{min}\right.$, $120 \mathrm{~min}$ ) in a tube furnace (Carbolite, Modular Horizontal Tube Furnace, GHA 12/600) to develop the extended surface area and porous structure of ZBAC [39]. In the impregnation step, bagasse was pyrolyzed at $250{ }^{\circ} \mathrm{C}$ for $120 \mathrm{~min}$ at first, then the $\mathrm{ZnCl}_{2}$ was added to bagasse (impregnation ratio = 2:1, $w / w)$, and finally, the mixture was desiccated at $100{ }^{\circ} \mathrm{C}$ for $24 \mathrm{~h} \mathrm{[40].} \mathrm{The} \mathrm{sample} \mathrm{of} \mathrm{the} \mathrm{impregnation}$ step was called $\mathrm{ZnCl}_{2}$ impregnated bagasse (ZIB). The sample prepared without activation by $\mathrm{ZnCl}_{2}$ was named bagasse activated carbon (BAC).

\subsection{Characterization}

Morphological and structural analysis of bagasse and ZBAC surface was imaged using HitachiTM 3030(Hitachi, Ltd, Tokyo, Japan). Using Micromeritics ASAP 2020 (Micromeritics Instrument Corp, Norcross, USA) to determine the $\mathrm{S}_{\mathrm{BET}}, \mathrm{V}_{\mathrm{mic}}$, and $\mathrm{D}_{\mathrm{P}}$ of the BAC and ZBAC. Crystallographic characterization was determined by XPert Pro (PANalytical, Malvern, WR14 1XZ, United Kingdom). Thermogravimetric experiments of bagasse and ZIB were tested using a thermogravimetric analyzer (HITACHI, STA7300, Hitachi, Ltd, Tokyo, Japan). FTIR analysis of bagasse and ZBAC were recorded using Nicolet 6700 spectrometer (Thermo Fisher Scientific, Waltham, MA USA 02451). Zeta potential analysis of ZBAC under diverse $\mathrm{pHs}$ (tested by PHS-3C, INESA Scientific Instrument Co., Ltd, Shanghai, China) was performed using Zetasizer Nano (Series Nano-ZS, Malvern, WR14 1XZ, United Kingdom). Surface chemical groups of the ZBAC and loaded ZBAC were analyzed by X-ray photoelectron spectroscopy (ESCALAB 250Xi, Thermo Fisher Scientific, Waltham, MA USA 02451). 


\subsection{Adsorption Experiments}

ZBAC $(0.1,0.2,0.3,0.4$, and $0.5 \mathrm{~g})$ were put into TCH solution $\left(C_{0}=120-240 \mathrm{mg} \mathrm{L}^{-1}, \mathrm{~V}=50 \mathrm{~mL}\right.$, $\mathrm{pH}=3.5)$ in batch adsorption. The experimental parameters were described in detail in the figure caption. The mixed solution was shaken at different temperature $(298,303$, and $313 \mathrm{~K})$ for $48 \mathrm{~h}$ to ensure equilibrium adsorption was reached [41].

Fixed bed adsorption was performed in a glass column $(\varphi=12.5 \mathrm{~mm}, \mathrm{H}=60 \mathrm{~mm})$. Different masses of ZBAC $(0.8,1.0$, and $1.2 \mathrm{~g})$ were added at the bottom of the glass column, filling the remaining part with quartz sand [30]. TCH concentrations were recorded at $274 \mathrm{~nm}$ by using UV-Visible spectrometer (SHIMADZU UV-1800, Kyoto, Japan) to obtain a breakthrough curve [42].

$\mathrm{TCH}\left(240 \mathrm{mg} \mathrm{L}^{-1}\right)$ loaded ZBAC with the same mass was desorbed by anhydrous alcohol at three flow rates $\left(1.0,1.5\right.$, and $\left.2.0 \mathrm{~mL} \mathrm{~min}^{-1}\right)$, and a breakthrough curve was drawn accordingly.

\section{Conclusions}

Adsorption and desorption behaviors and mechanisms of bagasse-based activated carbon activated with $\mathrm{ZnCl}_{2}$ for $\mathrm{TCH}$ removal were studied by adsorption experiments, morphology characteristics and chemical properties analysis. The optimal ZBAC which had a maximum value of $S_{B E T}$ as $831.23 \mathrm{~m}^{2} \mathrm{~g}^{-1}$, a $V_{\text {mic }}$ as $0.453 \mathrm{~cm}^{3} \mathrm{~g}^{-1}$, a $D p$ as $2.519 \mathrm{~nm}$ that were obtained by these conditions as follows: $2: 1$ impregnation ratio, $600{ }^{\circ} \mathrm{C}$ pyrolysis temperature for $120 \mathrm{~min}$. The maximum adsorption capacity of ZBAC was $239.6 \mathrm{mg} \mathrm{g}^{-1}$ in this paper. The equilibrium data in batch adsorption experiments fitted well with Model II, Model ID, and Model F. Six mathematical models were used to fit the breakthrough curve in the fixed bed adsorption experiment, coming out that Dose Response model was the most fitted for the fixed bed model of ZBAC adsorption TCH. The elution curves were studied by using anhydrous alcohol. The slower flow rate was beneficial to increase $C_{p}$ and $C F_{p}$, but desorption efficiency was lower overall. Some of the TCH remained at the adsorption site of ZBAC, which was considered to be irreversible adsorption. It was speculated that there were two adsorption mechanisms for TCH on ZBAC: a) Intraparticle diffusion on ZBAC, and b) $\pi-\pi$ interaction and cation $-\pi$ bonding between $\mathrm{ZBAC}$ and TCH. The desorption mechanism was that the hydrogen bond in the ethanol bound to the hydrogen bond receptor on the TCH, separating the TCH from the ZBAC. This study provides an important reference for a deeper understanding of the adsorption and desorption mechanisms of TCH on ZBAC. ZBAC as a recyclable renewable bio-resource material has potential in wastewater disposal.

Supplementary Materials: The following are available online, Figure S1: (a) XRD patterns of bagasse and ZBAC; (b) FT-IR spectra of bagasse, ZBAC and loaded ZBAC; Figure S2: TGA/DTG curves for bagasse and ZIB (a) bagasse, (b) ZIB. Tables S1: $\mathrm{S}_{\mathrm{BET}}, \mathrm{D}_{\mathrm{P}}$ and $\mathrm{V}_{\mathrm{mic}}$ of BAC and ZBAC; Tables S2: Kinetic Parameters of TCH Removal onto ZBAC; Tables S3: $R_{L}$ values at various temperatures and initial concentrations; Tables S4: Constant parameter and correlation coefficients calculated for various adsorption models at different temperatures for TCH on ZBAC; Tables S5: Adams-Bohart, Thomas, Yoon-Nelson, BDST, Dose Response and Clark Model.

Author Contributions: Conceptualization, X.L. and H.T.; methodology, Y.C. and L.L.; formal analysis, Y.C. and L.L.; data curation, Y.C.; writing-original draft preparation, Y.C.; writing-review and editing, X.L., Z.Y. and H.T.; project administration, Y.C. and X.L.; funding acquisition, X.L., Z.Y. and H.T.

Funding: This work was supported by the National Natural Science Foundation of China (Grant No. 51773159, 51303142), and Outstanding Young and Middle-aged Scientific Innovation Team of Colleges and Universities of Hubei Province: "Biomass chemical technologies and materials" (Grant No. T201908), the Science and Technology Planning Program of Guangdong (No. 2015A010105018), and the Special fund of Guangdong Academy of Science, grant number (No. 2018GDASCX-0105).

Conflicts of Interest: The authors declare no conflict of interest.

\section{Abbreviations}

$\mathrm{S}_{\text {BET }} \quad$ Brunauer-Emmett-Teller surface area $\left(\mathrm{m}^{2} \mathrm{~g}^{-1}\right)$

$\mathrm{V}_{\text {mic }} \quad$ Micropore volume $\left(\mathrm{cm}^{3} \mathrm{~g}^{-1}\right)$

$\mathrm{D}_{\mathrm{p}} \quad$ Average pore diameter $(\mathrm{nm})$

$\mathrm{q}_{\mathrm{m}} \quad$ Maximum adsorption capacity of TCH per unit mass of ZBAC $\left(\mathrm{mg} \mathrm{g}^{-1}\right)$ 
$\mathrm{q}_{\mathrm{t}} \quad$ Amounts of $\mathrm{TCH}$ adsorbed at contact time $\left(\mathrm{mg} \mathrm{g}^{-1}\right)$

$\mathrm{q}$ Amounts of $\mathrm{TCH}$ adsorbed at equilibrium time $\left(\mathrm{mg} \mathrm{g}^{-1}\right)$

$\mathrm{k}_{1} \quad$ Rate constant for first order kinetic $\left(\mathrm{min}^{-1}\right)$

$\mathrm{k}_{2} \quad$ Rate constant for second order kinetic $\left(\mathrm{g} \mathrm{mg}^{-1} \mathrm{~min}^{-1}\right)$

$\mathrm{k}_{0} \quad$ Initial adsorption rate $\left(\mathrm{g} \mathrm{mg}^{-1} \mathrm{~min}^{-1}\right)$

$\mathrm{K} \quad$ Langmuir adsorption constant $\left(\mathrm{L} \mathrm{mg}^{-1}\right)$

$\mathrm{R}_{\mathrm{L}} \quad$ Dimensionless constant separation factor

$\mathrm{k}_{\mathrm{f}} \quad$ Freundlich constant which indicates the adsorption capacity

$\mathrm{n} \quad$ Freundlich constant which related to the adsorption strength of the adsorbent

$\varepsilon \quad$ Polanyi potential

$\mathrm{K}^{\prime} \quad$ Constant of the adsorption energy $\left(\mathrm{mol}^{2} \mathrm{~kJ}^{-2}\right.$ )

$\mathrm{K}_{\mathrm{i}} \quad$ Rate constant of the intraparticle diffusion $\left(\mathrm{mg} \mathrm{g}^{-1} \mathrm{~min}^{-1 / 2}\right)$

E Adsorption energy $\left(\mathrm{kJ} \mathrm{mol}^{-1}\right)$

$\mathrm{pH}_{\mathrm{pzc}} \quad \mathrm{pH}$ at point of zero charge

$\mathrm{H} \quad$ Bed height in fixed bed column adsorption $(\mathrm{cm})$

Q Flow rate $\left(\mathrm{mL} \mathrm{min}^{-1}\right)$

$t_{b} \quad$ Breakthrough time (min)

$\mathrm{V}_{\mathrm{b}} \quad$ Volume of treated solution (mL)

$\mathrm{q}_{\mathrm{b}} \quad$ Adsorption capacity in Fixed bed adsorption $\left(\mathrm{mg} \mathrm{g}^{-1}\right)$

$R_{b} \quad$ Metal removal efficiency of the breakthrough point (\%)

$\mathrm{t}_{\mathrm{s}} \quad$ Saturation time ( $\left.\mathrm{min}\right)$

$\mathrm{V}_{\mathrm{s}} \quad$ Volume of treated solution $(\mathrm{mL})$

$\mathrm{q}_{\mathrm{s}} \quad$ Adsorption capacity in Fixed bed adsorption $\left(\mathrm{mg} \mathrm{g}^{-1}\right)$

$\mathrm{R}_{\mathrm{S}} \quad$ Metal removal efficiency of the saturation point (\%)

M Adsorbent dosage (g)

EBCT Empty bed contact time (min)

MTZ Mass transfer zone $(\mathrm{cm})$

$\mathrm{C}_{\mathrm{f}} \quad$ Desorbed concentration of $\mathrm{TCH}$

$\mathrm{q}_{\mathrm{e}, \mathrm{d}} \quad$ The amount of TCH desorbed

$q_{\text {total,d }}$ Amount of TCH desorbed per mass of ZBAC

$C_{p} \quad$ The maximum concentration in desorption

$\mathrm{CF}_{\mathrm{p}}$ The overall sorption process concentration factor

\section{References}

1. Ocampo-Pérez, R.; Rivera-Utrilla, J.; Gómez-Pacheco, C.; Sánchez-Polo, M.; López-Peñalver, J.J. Kinetic study of tetracycline adsorption on sludge-derived adsorbents in aqueous phase. Chem. Eng. J. 2012, 213, 88-96. [CrossRef]

2. Parolo, M.E.; Savini, M.C.; Vallés, J.M.; Baschini, M.T.; Avena, M.J. Tetracycline adsorption on montmorillonite: pH and ionic strength effects. Appl. Clay Sci. 2008, 40, 179-186. [CrossRef]

3. Gao, Y.; Li, Y.; Zhang, L.; Huang, H.; Hu, J.; Shah, S.M.; Su, X. Adsorption and removal of tetracycline antibiotics from aqueous solution by graphene oxide. J. Colloid Interface Sci. 2012, 368, 540-546. [CrossRef] [PubMed]

4. Ji, L.L.; Chen, W.; Duan, L.; Zhu, D.Q. Mechanisms for strong adsorption of tetracycline to carbon nanotubes: A comparative study using activated carbon and graphite as adsorbents. Environ. Sci. Technol. 2009, 43, 2322-2327. [CrossRef] [PubMed]

5. Zhang, W.; Lu, Y.; Sun, H.; Zhang, Y.; Zhou, M.; Song, Q.; Gao, Y. Effects of multi-walled carbon nanotubes on pyrene adsorption and desorption in soils: The role of soil constituents. Chemosphere 2019, 221, $203-211$. [CrossRef] [PubMed]

6. Garg, U.K.; Kaur, M.P.; Sud, D.; Garg, V.K. Removal of hexavalent chromium from aqueous solution by adsorption on treated sugarcane bagasse using response surface methodological approach. Desalination 2009, 249, 475-479. [CrossRef]

7. Yu, Z.; Peldszus, S.; Huck, P.M. Adsorption of selected pharmaceuticals and an endocrine disrupting compound by granular activated carbon. 2. Model prediction. Environ. Sci. Technol. 2009, 43, 1474-1479. [CrossRef] 
8. Lin, Y.C.; Cho, J.; Tompsett, G.A.; Westmoreland, P.R.; Huber, G.W. Kinetics and Mechanism of Cellulose Pyrolysis. J. Phys. Chem. C 2009, 113, 20097-20107. [CrossRef]

9. Ahmadpour, A.; Do, D.D. The preparation of activated carbon from macadamia nutshell by chemical activation. Carbon 1997, 35, 1723-1732. [CrossRef]

10. Yubing, S.; Shubin, Y.; Yue, C.; Congcong, D.; Wencai, C.; Xiangke, W. Adsorption and desorption of U(VI) on functionalized graphene oxides: a combined experimental and theoretical study. Environ. Sci. Technol. 2015, 49, 4255-4262. [CrossRef]

11. Kumar, A.; Mohan Jena, H. High surface area microporous activated carbons prepared from Fox nut (Euryale ferox) shell by zinc chloride activation. Appl. Surf. Sci. 2015, 356, 753-761. [CrossRef]

12. Ozdemir, I.; Şahin, M.; Orhan, R.; Erdem, M. Preparation and characterization of activated carbon from grape stalk by zinc chloride activation. Fuel Process. Technol. 2014, 125, 200-206. [CrossRef]

13. Li, H.; Hu, J.; Meng, Y.; Su, J.; Wang, X. An investigation into the rapid removal of tetracycline using multilayered graphene-phase biochar derived from waste chicken feather. Sci. Total Environ. 2017, 603-604, 39-48. [CrossRef] [PubMed]

14. Chen, A.; Shang, C.; Shao, J.; Lin, Y.; Luo, S.; Zhang, J.; Huang, H.; Lei, M.; Zeng, Q. Carbon disulfide-modified magnetic ion-imprinted chitosan-Fe(III): A novel adsorbent for simultaneous removal of tetracycline and cadmium. Carbohydr. Polym. 2017, 155, 19-27. [CrossRef]

15. Shan, D.; Deng, S.; Zhao, T.; Yu, G.; Winglee, J.; Wiesner, M.R. Preparation of regenerable granular carbon nanotubes by a simple heating-filtration method for efficient removal of typical pharmaceuticals. Chem. Eng. J. 2016, 294, 353-361. [CrossRef]

16. Ahmed, M.J.; Islam, M.A.; Asif, M.; Hameed, B.H. Human hair-derived high surface area porous carbon material for the adsorption isotherm and kinetics of tetracycline antibiotics. Bioresour. Technol. 2017, 243. [CrossRef]

17. Chen, Y.; Wang, F.; Duan, L.; Yang, H.; Gao, J. Tetracycline adsorption onto rice husk ash, an agricultural waste: Its kinetic and thermodynamic studies. J. Mol. Liq. 2016, 222, 487-494. [CrossRef]

18. Liao, P.; Zhan, Z.; Dai, J.; Wu, X.; Zhang, W.; Wang, K.; Yuan, S. Adsorption of tetracycline and chloramphenicol in aqueous solutions by bamboo charcoal: A batch and fixed-bed column study. Chem. Eng. J. 2013, 228, 496-505. [CrossRef]

19. Liu, P.; Liu, W.J.; Jiang, H.; Chen, J.J.; Li, W.W.; Yu, H.Q. Modification of bio-char derived from fast pyrolysis of biomass and its application in removal of tetracycline from aqueous solution. Bioresour. Technol. 2012, 121, 235-240. [CrossRef]

20. Luo, X.; Lei, X.; Cai, N.; Xie, X.; Xue, Y.; Yu, F. Removal of Heavy Metal Ions from Water by Magnetic Cellulose-Based Beads with Embedded Chemically Modified Magnetite Nanoparticles and Activated Carbon. ACS Sustain. Chem. Eng. 2016, 4, 3960-3969. [CrossRef]

21. Ahmad, Z.U.; Yao, L.G.; Wang, J.; Gang, D.D.; Islam, F.; Lian, Q.Y.; Zappi, M.E. Neodymium embedded ordered mesoporous carbon (OMC) for enhanced adsorption of sunset yellow: Characterizations, adsorption study and adsorption mechanism. Chem. Eng. J. 2019, 359, 814-826. [CrossRef]

22. Luo, X.; Lei, X.; Xie, X.; Yu, B.; Cai, N.; Yu, F. Adsorptive removal of Lead from water by the effective and reusable magnetic cellulose nanocomposite beads entrapping activated bentonite. Carbohydr. Polym. 2016, 151, 640-648. [CrossRef] [PubMed]

23. Lei, X.; Dai, X.; Long, S.; Cai, N.; Ma, Z.; Luo, X. Facile Design of Green Engineered Cellulose/Metal Hybrid Macrogels for Efficient Trace Phosphate Removal. Ind. Eng. Chem. Res. 2017, 56, 7525-7533. [CrossRef]

24. Naeem, A.; Westerhoff, P.; Mustafa, S. Vanadium removal by metal (hydr)oxide adsorbents. Water Res. 2007, 41, 1596-1602. [CrossRef] [PubMed]

25. Luo, X.; Zeng, J.; Liu, S.; Zhang, L. An effective and recyclable adsorbent for the removal of heavy metal ions from aqueous system: Magnetic chitosan/cellulose microspheres. Bioresour. Technol. 2015, 194, 403-406. [CrossRef]

26. Luo, X.; Liu, C.; Yuan, J.; Zhu, X.; Liu, S. Interfacial Solid-Phase Chemical Modification with Mannich Reaction and Fe(III) Chelation for Designing Lignin-Based Spherical Nanoparticle Adsorbents for Highly Efficient Removal of Low Concentration Phosphate from Water. ACS Sustain. Chem. Eng. 2017, 5, 6539-6547. [CrossRef]

27. Kul, A.; Koyuncu, H. Adsorption of $\mathrm{Pb}$ (II) Ions From Aqueous Solution by Native and Activated Bentonite: Kinetic, Equilibrium and Thermodynamic Study. J. Hazard. Mater. 2010, 179, 332-339. [CrossRef] 
28. Luo, X.; Cai, Y.; Liu, L.; Zeng, J. Cr(VI) adsorption performance and mechanism of an effective activated carbon prepared from bagasse with a one-step pyrolysis and $\mathrm{ZnCl} 2$ activation method. Cellulose 2019, 26, 4921-4934. [CrossRef]

29. Cai, Y.; Liu, C.; Lu, Y.; Luo, X.; Zeng, J. Bagasse-based adsorbent with nitric acid esterification and Fe(iii) chelation for the highly efficient removal of low concentration phosphate from water. New J. Chem. 2019, 43, 2966-2973. [CrossRef]

30. Luo, X.; Yuan, J.; Liu, Y.; Liu, C.; Zhu, X.; Dai, X.; Ma, Z.; Wang, F. Improved Solid-Phase Synthesis of Phosphorylated Cellulose Microsphere Adsorbents for Highly Effective Pb2+ Removal from Water: Batch and Fixed-Bed Column Performance and Adsorption Mechanism. ACS Sustain. Chem. Eng. 2017, 5, 5108-5117. [CrossRef]

31. Wan Ngah, W.S.; Teong, L.C.; Toh, R.H.; Hanafiah, M.A.K.M. Utilization of chitosan-zeolite composite in the removal of $\mathrm{Cu}(\mathrm{II})$ from aqueous solution: Adsorption, desorption and fixed bed column studies. Chem. Eng. J. 2012, 209, 46-53. [CrossRef]

32. Bulgariu, D.; Bulgariu, L. Sorption of $\mathrm{Pb}(\mathrm{II})$ onto a mixture of algae waste biomass and anion exchanger resin in a packed-bed column. Bioresour. Technol. 2013, 129, 374-380. [CrossRef] [PubMed]

33. Calero, M.; Hernáinz, F.; Blázquez, G.; Tenorio, G.; Martínlara, M.A. Study of Cr (III) biosorption in a fixed-bed column. J. Hazard. Mater. 2009, 171, 886-893. [CrossRef] [PubMed]

34. Aschermann, G.; Zietzschmann, F.; Jekel, M. Influence of dissolved organic matter and activated carbon pore characteristics on organic micropollutant desorption. Water Res. 2018, 133, 123-131. [CrossRef]

35. Martín-Lara, M.A.; Blázquez, G.; Ronda, A.; Rodríguez, I.L.; Calero, M. Multiple biosorption-desorption cycles in a fixed-bed column for $\mathrm{Pb}$ (II) removal by acid-treated olive stone. J. Ind. Eng. Chem. 2012, 18, 1006-1012. [CrossRef]

36. Lodeiro, P.; Herrero, R.; Sastre de Vicente, M.E. Batch desorption studies and multiple sorption-regeneration cycles in a fixed-bed column for Cd(II) elimination by protonated Sargassum muticum. J. Hazard. Mater. 2006, 137, 1649-1655. [CrossRef]

37. Qu, R.; Feng, M.; Wang, X.; Qin, L.; Wang, C.; Wang, Z.; Wang, L. Metal accumulation and oxidative stress biomarkers in liver of freshwater fish Carassius auratus following in vivo exposure to waterborne zinc under different pH values. Aquat. Toxicol. 2014, 150, 9-16. [CrossRef]

38. Barroso-Bogeat, A.; Alexandre-Franco, M.; Fernández-González, C.; Gómez-Serrano, V. Activated carbon surface chemistry: Changes upon impregnation with $\mathrm{Al}(\mathrm{III}), \mathrm{Fe}(\mathrm{III})$ and $\mathrm{Zn}(\mathrm{II})$-metal oxide catalyst precursors from NO3- aqueous solutions. Arab. J. Chem. 2016. [CrossRef]

39. Acharya, J.; Sahu, J.N.; Sahoo, B.K.; Mohanty, C.R.; Meikap, B.C. Removal of chromium(VI) from wastewater by activated carbon developed from Tamarind wood activated with zinc chloride. Chem. Eng. J. 2009, 150, 25-39. [CrossRef]

40. Angin, D. Production and characterization of activated carbon from sour cherry stones by zinc chloride. Fuel 2014, 115, 804-811. [CrossRef]

41. Antón-Herrero, R.; García-Delgado, C.; Alonso-Izquierdo, M.; García-Rodríguez, G.; Cuevas, J.; Eymar, E. Comparative adsorption of tetracyclines on biochars and stevensite: Looking for the most effective adsorbent. Appl. Clay Sci. 2018, 160, 162-172. [CrossRef]

42. Song, Q.; Fang, Y.; Liu, Z.; Li, L.; Wang, Y.; Liang, J.; Huang, Y.; Lin, J.; Hu, L.; Zhang, J.; et al. The performance of porous hexagonal $\mathrm{BN}$ in high adsorption capacity towards antibiotics pollutants from aqueous solution. Chem. Eng. J. 2017, 325, 71-79. [CrossRef]

Sample Availability: Samples of the compounds are not available from the authors. 